\title{
Bauran Pemasaran di Tempat Pemotongan Hewan (TPH) Sumber Rezeki
}

\section{Marketing Mix in the Sumber Rejeki Slaughterhouse (TPH)}

\author{
F. D. Perwitasari* dan Bastoni \\ Universitas Muhammadiyah Cirebon - Indonesia \\ *Corresponding E-mail: caraka20@gmail.com \\ (Diterima: 21 Oktober 2020; Disetujui: 19 Januari 2021)
}

\begin{abstract}
ABSTRAK
Tempat pemotongan hewan (TPH) Sumber Rejeki berada di Desa Batembat Kecamatan Tengah Tani Kabupaten Cirebon usaha ini sudah berdiri sejak tahun 2000 pusat penjualan daging kerbau dan sapi dan tahun TPH Sumber Rejeki tahun 2005 sampai sekarang juga menjual hewan qurban, menyediakan jasa pemotongan hewan qurban dan pusat penjualan daging kerbau dan sapi. Oleh sebab penelitian ini bertujuan untuk mengetahui bauran pemasaran di TPH Sumber Rejeki. Penelitian dilaksanakan di bulan September Desember 2018 dan menggunakan metode studi kasus. Pemilihan lokasi ini menggunakan purposive random sampling dikarenakan 1. Pemilik TPH Sumber Rezeki merupakan Ketua dari Perkumpulan Para Pengusaha Tempat Pemotongan Hewan, 2. TPH ini mendapat pengawasan dan pembinaan dari Dinas Pertanian, Perkebunan, Peternakan, dan Kehutanan (DISTANBUNNAKHUT) Kabupaten Cirebon, Jawa Barat, 3. TPH Sumber Rejeki telah terdaftar sebagai perusahaan perorangan dengan nomor TDP 102255208696 (DISPERIDAG Kabupaten Cirebon). Hasil dari penelitian ini kegiatan marketing mix yang modern terdiri 7P (product, place, price, promotion people, physical evidence dan customer service), sedangkan bauran pemasaran yang ada di TPH Sumber Rejeki masih semi tradisional dimana sistemnya sudah menggunakan teknologi tetapi belum semuanya.
\end{abstract}

Kata kunci: marketing mix, TPH Sumber Rejeki, daging sapi dan kerbau

\section{ABSTRACT}

Sumber Rejeki slaughterhouse (TPH) located in Batembat Village, Tengah Tani Regency Cirebon District business established in 2000, the center of selling buffalo and beef and TPH Sumber Rejeki from 2005 to the present day also sells Idul Adha animals, provides services Idul Adha slaughterhouses and buffalo and beef sales centers. Therefore this research aims to find out the marketing mix at TPH Sumber Rejeki. The research conducted in September - December 2018 and using the case study method. The location selection used purposive random sampling because 1. The owner of TPH Sumber Rezeki is the Chairman of the Entrepreneurs' Association Slaughterhouses, 2. This TPH receives supervision and guidance from the Agriculture Office, Plantation, Animal Husbandry and Forestry (DISTANBUNNAKHUT) Cirebon Regency, West Java, 3. TPH Sumber Rejeki registered as an individual company with a TDP number 102255208696 (DISPERIDAG Cirebon Regency). The results of this study consisted of a modern marketing mix $7 P$ (product, place, price, promotion people, physical evidence, and customer service), the mix existing marketing at Sumber Rejeki TPH is still semi-traditional the system is already in use technology but not all.

Keywords: mix marketing, TPH Sumber Rejeki, beef, and buffalo

\section{PENDAHULUAN}

Usaha Peternakan dapat memberikan kontribusi terhadap perekonomian masyarakat selain usaha budidaya ternak, ada usaha lain adalah Tempat Pemotongan Hewan (TPH). Tempat Pemotongan Hewan mempunyai peran sebagai Sub Sistem Pemasaran Hasil Ternak dalam penyediaan daging sapi dan kerbau (Azwanda et al., 2017). Pemerintah 
perlu mempersiapkan sarana dan prasarana RPH atau dan pengawasan serta pembinaan TPH di daerah sesuai SOP standart RPH atau $\mathrm{TPH}$, agar masyarakat bisa mendapatkan daging yang aman, sehat, utuh dan halal. Apalagi dengan meningkatnya impor daging tentu jumlah pemotongan akan semakin meningkat juga.

Bauran pemasaran awalnya terdiri dari $4 \mathrm{P}$ adalah produk, price, promosion dan place, dimana memiliki peran dalam keberhasilan manajemen pemasaran yang ditunjukan dengan respon dari pasar terhadap produk dan sangat penting dalam membangun komitmen dan loyalitas pelanggan (Selang, 2013). Menurut Kotler (2005) mengatakan bahwa bauran pemasaran untuk sektor jasa memiliki tambahan empat unsur lainnya, yaitu people (orang), process (proses), physical evidence (bukti fisik) dan customer service (layanan pelanggan).

Tempat pemotongan hewan (TPH) Sumber Rejeki berada di Desa Batembat Kecamatan Tengah Tani Kabupaten Cirebon usaha ini sudah berdiri sejak tahun 2000 pusat penjualan daging kerbau dan sapi dan tahun TPH Sumber Rejeki tahun 2005 sampai sekarang juga menjual hewan qurban, menyediakan jasa pemotongan hewan qurban dan pusat penjualan dan distribusi daging kerbau dan sapi wilayah Cirebon dan Indramayu. Oleh sebab itulah penelitian bertujuan untuk mengetahui bauran pemasaran dengan sistem 7P di TPH Sumber Rezeki.

\section{METODE}

\section{Tempat dan Waktu Penelitian}

Tempat penelitian dilaksanakan di TPH Sumber Rezeki Desa Tengah Tani Kabupaten Cirebon. Waktu penelitian dilaksanakan bulan September - Desember 2018.

\section{Metode Penelitian}

Metode Penelitian mengunakan metode studi kasus. Pemilihan lokasi ini menggunakan purposive random sampling dikarenakan 1. Pemilik TPH Sumber Rezeki merupakan Ketua dari Perkumpulan Para Pengusaha Tempat Pemotongan Hewan, 2. TPH ini mendapat pengawasan dan pembinaan dari (DISTANBUNNAKHUT) Kabupaten Cirebon, Jawa Barat, 3. TPH Sumber Rejeki telah terdaftar sebagai perusahaan perorangan dengan nomor TDP 102255208696 (DISPERINDAG) Kabupaten Cirebon, Jawa Barat. Data primer diperoleh dari hasil wawancara dengan pemilik dan para pegawai TPH Sumber Rejeki yang terkait dengan managemen pemasaran (produk, harga, tempat dan promosi, people (orang), process (proses), physical evidence (bukti fisik) dan customer service (layanan pelanggan). Data sekunder berasal dari dinas Pertanian Kabupaten Cirebon dan literatur jurnal penelitian, buku, artikel ilmiah. Analisis data dijelaskan secara deskriptif.

\section{HASIL DAN PEMBAHASAN}

Bauran pemasaran (Marketing mix) meliputi 4 aspek yang mengendalikan secara teknis pemasaran dengan tujuan memberikan respon yang diinginkan konsumen. Menurut pendapat Kotler dan Armstrong (2008) mengemukakan bahwa pendekatan bauran pemasaran $7 \mathrm{P}$ (product, price, place, promotion, people (orang), process (proses), physical evidence (bukti fisik) dan customer service (layanan pelanggan).

\section{Produk TPH Sumber Rejeki}

Pengembangan produk TPH Sumber Rejeki yang akan dibahas dalam penelitian ini dilihat dari yaitu: 1) jenis produk TPH Sumber Rejeki, 2) merk dagang, 3) kemasan daging dan 4) penjaminan mutu yang akan dijelaskan dibawah ini.

Produk awal dari TPH Sumber Reyeki berupa daging segar baik kerbau maupun sapi. Produk memiliki siklus hidup dan pangsa pasar yang berbeda oleh sebab itulah pihak TPH Sumber Rejeki melakukan pengembangan produk dimulai tahun 2010 dengan merespon permintaan pasar. Hal ini sesuai dengan pendapat Kotler (2005) mengatakan bahwa, 
produk merupakan segala sesuatu baik dalam bentuk barang atau jasa yang ditawarkan ke pasar untuk diperhatikan, diperoleh, digunakan, atau dikonsumsi dengan tujuan dapat memenuhi kebutuhan konsumen.

TPH Sumber Rejeki sebagai distributor daging beku, sejak tahun 2010. Penjualan daging beku, hal ini dilakukan dengan alasan: a. Konsumen mulai menyadari pentingnya konsumsi protein hewani, b. Konsumen ingin daging murah terutama untuk para pedagang bakso, c. Kualitas juga tidak kalah dari daging segar. Kandungan gizi makro dan keadaan fisik daging beku dan daging segar di pasar tradisonal dan pasar swalayan tidak berbeda nyata dengan nilai $\mathrm{pH}$ daging $(5,1-6,1)$ (Emawati et al., 2018)

Daging beku yang dijual oleh TPH Sumber Rejeki berasal dari negara Australia dan New Zealand untuk sapi sedangkan untuk daging kerbau berasal dari India. Daging import yang diperoleh pihak TPH Sumber Rejeki kerjasama dengan perusahaan dari Jakarta yaitu PT Sarana Inti Pangan, PT Segar Baru Abadi, dan PT Dua Putra Perkasa.

TPH Sumber Rejeki melakukan diversifikasi produk pertama sejak tahun 2013 dengan mulai membuka usaha rumah makan Empol Gentong Hj. Dian. Empol Gentong merupakan masakan kuliner ciri khas Cirebon yang berbahan baku utamanya menggunakan daging. Usaha kuliner ini sangat menjanjikan dan dipandang mempunyai prospek yang bagus. TPH Sumber Rejeki diversifikasi produk kedua pada tahun 2015 juga mulai mengolah kulit sapi bagian dalam menjadi rambak kemudian digoreng seperti krupuk rampak yang dijual di restoran Empol Gentong Hj Dian juga menjual oleh-oleh khas Cirebon lainnya, sedangkan kulit bagian luar dilakukan penggaram dan dijualkan ke industri kulit. Hal ini dapat disimpulkan bahwa TPH Sumber Rejeki melakukan diversikasi produk dari produk utama sampai produk ikutan juga diolah, sehingga tidak ada yang terbuang.

Merek dagang merupakan identitas yang melekat pada produk, sehingga memiliki manfaat untuk menarik citra atau image yang baik di mata konsumen (Firmansyah, 2019). TPH Sumber Rejeki sudah memiliki merk dagang yaitu berupa tulisan SUMBER REJEKI (brand name), yang artinya TPH ini mempunyai sumber rejeki untuk semua orang baik untuk keluarga besar H. Tori dan lingkungan sekitarnya. Artinya pembuatan merek dagang ini bukan hanya sebuah merek atau simbol saja akan tetapi juga mengandung doa untuk semua orang. Pembuatan merk berupa tulisan yang dibuat sementara ini baru diberikan ke nota pembelian dan seragam karyawan di TPH dan Restoran Hj. Dian.

Kemasan merupakan tempat atau penyimpanan bahan pangan yang aman sehingga diharapkan mempunyai umur simpan yang lama (Mutiara, 2018). Kemasan dalam pengiriman daging di TPH Sumber Rejeki, masih menggunakan plastik berwarna putih dan karung. Penggunan plastik putih dan karung ini dengan alasan: 1) mudah didapat, 2) harga terjangkau, 3) sekali buang, 4) muat banyak, 5) waktu sementara, karena jarak antara TPH dengan konsumen dekat. Hasil penelitian (Astuti et al., 2019) mengatakan bahwa kemasan yang digunakan untuk mengemas daging sapi pada swalayan Hypermart MATOS menggunakan starfoam dan plastic. Konsumen sangat memperhatikan bentuk kemasan dan kepraktisan membuka kemasan dan bahan kemasan. Kemasan merupakan hal penting untuk produk, karena hal ini dapat memberikan daya tarik ke konsumen. Oleh sebab itulah dalam pembuatan kemasan produk harus memperhitungkan biaya, kemanan pangan, tahan lama dan melindungi produk tersebut.

Penjaminan mutu TPH Sumber Rejeki yaitu 1) dengan bekerja sama dengan RPH Batembat, Dinas Pertanian Kabupaten Cirebon dan MUI di Kabupaten Cirbon, 2) menjaga kebersihan, keamanan dan membuat peraturan yang ketat untuk mendisplinkan para karyawan. Produk daging TPH Sumber Rejeki sudah mendapat sertifikat HALAL dari MUI dan setiap 5 tahun sekali memperpanjangnya. Hal ini sesuai dengan 
Tabel 1. Harga Bagian - Bagian Daging Sapi Segar dan Daging Sapi Beku di TPH Sumber Rejeki serta Beberapa Pasar di Daerah Cirebon.

\begin{tabular}{clcccc}
\hline No & $\begin{array}{l}\text { Nama Bagian } \\
\text { Daging Sapi }\end{array}$ & $\begin{array}{c}\text { Harga/Kg } \\
\text { di TPH } \\
(\mathrm{Rp})\end{array}$ & $\begin{array}{c}\text { Harga/Kg } \\
\text { dipasar Plered } \\
(\mathrm{Rp})\end{array}$ & $\begin{array}{c}\text { Harga/ } \\
\text { Kg dipasar } \\
\text { Kanoman }(\mathrm{Rp})\end{array}$ & $\begin{array}{c}\text { Harga/Kg } \\
\text { dipasar Baru } \\
\text { Indramayu }(\mathrm{Rp})\end{array}$ \\
\hline 1. & Has luar & 105.000 & 110.000 & 120.000 & 120.000 \\
2 & Has dalam & 110.000 & 115.000 & 130.000 & 130.000 \\
3. & Daging kepala & 80.000 & 70.000 & 90.000 & 90.000 \\
4. & Daging iga & 105.000 & 110.000 & 120.000 & 120.000 \\
5. & Tulang iga & 50.000 & 50.000 & 70.000 & 70.000 \\
6. & Gaji & 30.000 & 30.000 & 40.000 & 40.000 \\
7. & Putihan & 40.000 & 45.000 & 40.000 & 40.000 \\
8. & Klatak & 10.000 & 10.000 & 20.000 & 20.000 \\
9. & Urat & 70.000 & 70.000 & 80.000 & 80.000 \\
10. & Jantung & 80.000 & 80.000 & 90.000 & 90.000 \\
11. & Hati & 70.000 & 85.000 & 90.000 & 90.000 \\
12. & Paru & 80.000 & 85.000 & 80.000 & 80.000 \\
13. & Usus & 30.000 & 35.000 & 40.000 & 40.000 \\
14. & Babad & 45.000 & 45.000 & 40.000 & 40.000 \\
15. & Sumsum & 50.000 & 55.000 & 60.000 & 60.000 \\
16. & Otak & 50.000 & 55.000 & 50.000 & 50.000 \\
17. & Buntut & 60.000 & 50.000 & 80.000 & 80.000 \\
18. & Kepala & 40.000 & 45.000 & 50.000 & 50.000 \\
19. & Tulang & 40.000 & 45.000 & 55.000 & 55.000 \\
20. & Tulang kaki & $5000 /$ & $5.000 /$ & $15.000 /$ & $15.000 /$ \\
& & Buah & Buah & Buah & Buah \\
21. & Kulit & 15.000 &.- & - &.- \\
22. & Daging no 1 impor & 90.000 & 95.000 & 100.000 & 100.000 \\
23. & Daging no 2 impor & 65.000 & 70.000 & 75.000 & 75.000 \\
24. & Daging kepala & 60.000 & 65.000 & 70.000 & 70.000 \\
25. & Tongue root/isian & 45.000 & 45.000 & 55.000 & 55.000 \\
& bakso impor & & & & \\
\hline
\end{tabular}

Sumber: Data olahan, 2018

pendapat (Rosyidi, 2017) mengatakan bahwa untuk menghasilkan daging yang ASUH, maka dari itu harus memperhatikan yaitu 1 . Prosedur pemotongan sesuai dengan syariat islam, 2. Pemeriksaan ante mortem dan post mortem.

\section{Harga}

TPH Sumber Rejeki berlokasi dekat dengan RPH Batembat dan disekitar RPH Batembat terdapat juga kios-kios penjual daging dan TPH lain yang berada di wilayah Desa Battembat yang merupakan daerah tempat pejagalan. Oleh sebab itulah harga 
jual daging di TPH Sumber Rejeki dengan TPH lain dan Kios-kios penjual daging harga seragam. Harga jual daging sapi di TPH Sumber Rejeki disini sudah memperhitungkan juga biaya produksi, biaya transpotasi, biaya promosi dan biaya resiko. Biaya resiko merupakan biaya yang dibebankan oleh TPH Sumber Rejeki ke Pedagang pengeber (orang yang membeli daging ke TPH Sumber Rejeki kemudian untuk dijual lagi ke pasar-pasar yang ada di Cirebon), penjual bakso, catering dan Paketan (orang yang membeli daging ke TPH Sumber Rejeki untuk paket pada hari raya Idul Fitri). TPH Sumber Rejeki dengan alasan apabila ada Pedagang pengeber, penjual bakso, catering dan Paketan "Nakal" tidak mau membayar nota hasil pembelian daging maka pihak TPH Sumber Rejeki sudah dapat menutupi kekurangan tersebut dari biaya resiko yang dibebankan disetiap konsumen (Pedagang pengeber, penjual bakso, catering dan Paketan. Perhitungan dalam membuat harga produk harus memperimbangkan berapa komponen yang meliputi : 1) estimasi mengenai kepekaan pasar produk terhadap harga, 2) penentuan biaya produksi produk, 3) analisis persaingan, dan 4) penilaian terhadap hambatan-hambatan dari oknum dan etika (Budi et al., 2016).

Perbedaan harga daging menjelang hari (Idul Fitri dan Idul Adha), kenaikan harga ini berkisar antara $\mathrm{Rp} 10.000 / \mathrm{kg}$ sampai Rp20.000/kg semua bagian daging yang ada di Tabel 1. Kenaikan harga yang terjadi di TPH Sumber Rejeki sesuai dengan penelitian (Priyanti dan Inounu, 2016) yang menyatakan bahwa harga daging sapi menjelang Hari Besar keagamaan akan meningkat berkisar $10 \%-20 \%$.

Harga daging sapi di TPH Sumber Rejeki segar dan beku di setiap pasar berbeda, misal harga daging sapi segar sebesar $\mathrm{Rp}$ $110.000 / \mathrm{kg}$ dan daging beku sebesar $\mathrm{Rp}$ 95.000/kg di Pasar Plered, perbedaan harga ini dengan alasan: 1. Pasar Plered terdapat banyak kios-kios dan TPH penjual daging, sehingga terjadi persaingan harga, maka apabila harga yang dijual terlalu tinggi maka barang menjadi tidak laku. 2. Konsumen di pasar plered juga para pedagang pengeber, penjual bakso, dan Paketan.

Perbedaan harga daging segar dan

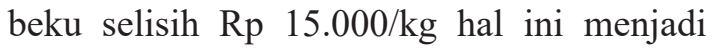
alasan konsumen di TPH Sumber Rejeki mau membeli daging beku terutama para penjual bakso keliling, segi kualitas juga tidak kalah dengan daging sapi segar, permintaan meningkat karena konsumen mulai sadar pentingnya protein hewani. Hal ini didukung dengan pendapat (Gunawan, 2013) mengatakan bahwa daging sapi import memilki rasa dan kualitas yang bagus dibandingkan sapi lokal, dimana dilihat dari keempukan, tasty, juiciness, dan gurih.

Perbedaan harga daging sapi segar $(\mathrm{Rp}$ $120.000 / \mathrm{kg}$ ) dan daging beku (Rp 100.000/ $\mathrm{kg}$ ) di pasar Kanoman dan Indramayu, alasannya: 1. Ada biaya transportasi yang harus dikeluarkan karena letaknya yang jauh. 2. konsumen daging sapi di Pasar ini kebanyakan adalah masyarakat dengan ekonomi menengah ke atas atau pembeli yang memiliki usaha catering, 3. Kualitas daging yang diminta oleh konsumen daging yang kualitas 1.

Hasil penjelasan diatas dapat
disimpulkan bahwa factor yang mempengaruhi harga jual daging adalah jarak tempat konsumen, pendapatan konsumen, harga daging sapi import. Hal ini sesuai dengan penelitian Priyanti dan Inounu (2016) dan (Firman et al., 2018) mengatakan bahwa tempat atau wilayah di Indonesia dapat mengalami perubahan harga secara signifikan.

Menurut pendapat (Handayani et al., 2016) mengatakan bahwa permintaan konsumsi daging sapi diikuti dengan peningkatan laju populasi penduduk sehingga mau tidak mau pemerintah mengadakan import daging. Produksi daging sapi dipengaruhi oleh 1) perubahan harga daging sapi domestik, 2) harga daging sapi impor dan 3) kebijakan swasembada daging sapi. Harga jual daging sapi dosmetik dipengaruhi oleh harga daging import dan tarif import. Harga sapi import 
lebih murah daripada harga sapi lokal, oleh sebab itulah RPH kota Bandung lebih banyak memotong sapi import dibandingkan sapi lokal untuk memenuhi kebutuhan daging yang terus meningkat (Narundhana et al., 2015).

\section{Tempat}

Tempat pemasaran termasuk sebagai saluran distribusi produk daging untuk sampai ke konsumen dengan cara yang paling efektif dan efisien, dengan memperhatikan pengaruh dari 1) sifat produk yang mudah rusak, 2) kebijakan perusahaan, 3) pedagang perantara dan 4) pesaing dan lingkungan perusahaan (Panjaitan dan Cahyanto, 2017).

RPH Sumber Rejeki mempunyai tempat pemasaran yang dijelasakan dalam penelitian ini yaitu 1. Lokasi usaha TPH Sumber Rejeki (Pusat), TPH Sumber Rejeki berlokasi di tempat yang cukup strategis, berjarak sekitar 50 meter dari jalan raya Plered yang juga merupakan komplek penjagalan dan pusat penjualan daging sapi dan kerbau di Kabupaten Cirebon. TPH Sumber Rejeki dan $\mathrm{RPH}$ Battembat hanya berjarak 500 meter. Kantor RPH milik dinas yang menangani bagian pengawasan mutu daging terletak di sebelah TPH. 2. Pasar yang dipilih oleh TPH Sumber Rejeki sebagai saluran distribusi ke konsumen. Pasar yang menjadi saluran distribusi daging TPH Sumber Rejeki meliputi Pasar Plered, Pasar Kanoman dan Pasar Indramayu, artinya pemilihan lokasi pasar dalam memasarkan produk daging merupakan salah satu cara untuk memotong saluran distribusi yang terlalu panjang sehingga produk bisa sampai ke konsumen langsung dan harga daging tidak terlalu tinggi. Hal ini sesuai dengan menurut pendapat Sumarni dan Soeprihanto (2010) mengatakan bahwa "Saluran distribusi yang digunakan oleh produsen untuk menyalurkan produk tersebut dari produsen sampai ke konsumen atau industri pemakai”. Pengembangan wilayah diluar CIAYUNAJAKUNING belum dilakukan oleh pihak TPH Sumber Rejeki, dikarenakan 1. Sarana transpotasi, 2. Packing, dan 3. Penyimpanan.

\section{Promosi}

Stategi promosi dalam penjualan produk dapat dilakukan dengan: 1) mengkombinasikan periklanan (advertising), 2) penjualan personal (personal selling), 3) promosi penjualan (sales promotion), 3) publisitas dan hubungan masyarakat (publicity and public relation), dan 3) pemasaran langsung (direct marketing) dalam suatu program terkoordinasi untuk berkomunikasi dengan pembeli dan pihak lainnya yang mempengaruhi keputusan pembelian (Budi et al., 2016).

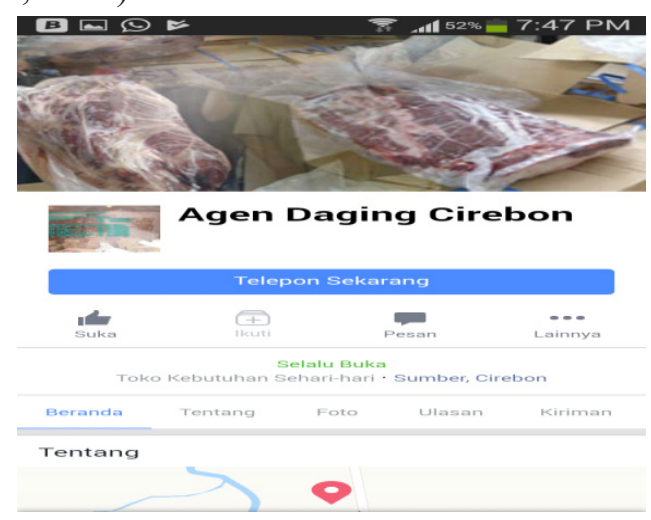

Gambar 1. Contoh Promosi di Media Sosial

Menurut pendapat Kotler (2014) mengatakan bahwa strategi promosi yang terdiri atas empat komponen utama yaitu: 1. Periklanan 2. Promosi penjualan dengan memberikan insentif jangka pendek untuk meningkatkan penjualan suatu produk atau jasa pada saat ini juga. 3. Hubungan masyarakat bertujuan untuk menumbuhkan citra perusahaan, dengan menggunakan sarana (siaran pers, publisitas produk, komunikasi perusahaan dan penyuluhan). 4. Penjualan perorangan dengan cara berwiraniaga. Strategi promosi yang dilakukan oleh TPH Sumber Rejeki sudah secara off line dan on line (Gambar 1). Secara on line 1) TPH Sumber Rejeki bekerja sama dengan UUT beef membuat website penjualan daging, 2) melalui media what's app (WA), Secara off line yaitu promosi dengan cara: 1 . Penyebaran brousur, iklan di media massa "Radar Cirebon", 2. Konsumen yang melakukan pembelian minimal 40 kilogram maka akan diberikan 
bonus tulang iga $(1-2 \mathrm{~kg})$. 3. Pembagian kaos gratis dan kalender tahunan ke pelanggan dan konsumen, 4. Untuk mengikat pelangan disetiap setahun sekali atau bertepatan dengan Idul Fitri TPH Sumber Rejeki memberikan hadiah bisa berupa daging atau barang-barang untuk pelanggan.

\section{People (Orang)}

TPH Sumber Rejeki memiliki 37 orang karyawan dengan bagian kerja sendiri yaitu bagian administrasi, bagian keamanan, bagian Pengawal ternak, Bagian pelayanan, Bagian Pemasaran, Bagian kebersihan, Bagian Gudang, Juru Sembelih, Bagian pemotong dan bagian distribusi. Karyawan berasal dari lingkungan sekitar Desa Battembat dengan sistem kerja harian dan shift. Pembagian shift diatur sendiri oleh karyawan. Ketika pemotongan sedang sepi maka pengupahan karyawan dihitung berdasarkan banyaknya ternak yang dipotong, namun pada saat idul fitri atau idul adha dihitungan dengan sistem borongan. Karyawan Sumber Rejeki setiap berangkat menggunakan seragam ada merk SUMBER REJEKI, Hal ini dilakukan oleh pihak Sumber Rejeki untuk 1. Pendisplin karyawan agar penggunan baju seragam, 2. Agar mudah dalam pengawasan, apabila ada pihak lain yang masuk akan langsung ketahuan. 3. Seragam yang dipakai dalam keadaan bersih. Karyawan Sumber Rejeki mempunyai peraturan yang tidak boleh dilanggar oleh karyawan yaitu 1) datang tepat waktu sesuai dengan shift kerjanya, 2) menggunakan seragam, 3) tidak boleh minuman keras atau merokok saat bekerja apabila melanggar akan diberikan sanksi teguran.

Orang adalah sumber daya yang mempunyai fungsi sebagai penggerak dalam sebuah usaha. Oleh sebab itu usaha dapat berjalan dengan lancar, karyawan perlu diberikan bonus dan pelatihan. Kegiatan untuk peningkatan loyalitas dan skill karyawan TPH Sumber Rejeki yaitu dengan 1) memberikan bonus dengan mengadakan Field Trip bagi seluruh karyawan. 2) Pelatihan untuk juru sembelih berasal dari Dinas Pertanian
Kabupaten Cirebon dan MUI Kabupaten Cirebon. Kualitas sumber daya manusia dapat meningkat dapat diberikan pelatihan, motivasi dan bonus untuk menyadari pentingnya pekerjaannya dan bentuk perhatian perusahaan (Dhiba dan Maduwinarti, 2014).

\section{Proses Produksi}

Proses produksi di TPH Sumber Rejeki terjadi beberapa tahap yaitu: 1) ternak datang, 2) proses penyembelihan, 3) proses pemotongan karkas 4) proses pelayuan, 5) proses pemasaran yang akan dijelaskan dibawah ini.

\section{Ternak Datang}

Ternak yang datang di TPH Sumber Rejeki dibahas berikut ini yaitu asal, jenis bangsa dan cara perlakuan ternak datang. Ternak yang datang di TPH Sumber Rejeki berasal dari daerah Jawa Tengah, seperti Pemalang, Kudus, Pati, dan Pekalongan, serta wilayah III Cirebon yang meliputi Cirebon, Majalengka, Indramayu, dan Kuningan.

Jenis ternak yang biasa dipotong yaitu PO, Simental, Limosin, Limpo dan BX berat hidup rata - rata $300 \mathrm{~kg}$ sampai 500 kg. Pemotong kerbau sangat jarang sekali biasanya bisa seminggu sekali pemotong kerbau 1- 2 ekor dengan berat hidupnya ratarata $300 \mathrm{~kg}$ sampai $500 \mathrm{~kg}$. Asal negara daging beku berasal dari Australia untuk daging sapi sedanngkan india untuk daging kerbau. Merek daging impor yang biasa dipesan oleh TPH Sumber Rejeki sangat beragam antara lain AL - TAMAM, AMH, RALPHS, AMG, AACO, AFCO,CASINO, ALLANA, BLACK GOLD, COLES, CLASIC, MERAMIST, IBP, GBP, MILDFIELD, MONBEEF, OAKEY, SWIFT, WMPG, MK, PPCS, dan TEYS.

Cara perlakuan ternak datang adalah ternak diistirahatkan dan dilakukan pemeriksaan antemortem. Pengistirahat ternak bersekitar 6 jam sampai 24 jam. Pengistirahat ini diletakan di kandang sementara dimana disediakan pakan dan minum. Menurut hasil penelitian (Bhaskara et al., 2015) mengatakan bahwa tempat penampungan di RPH Kota Madya Banda Aceh memenuhi syarat SOP 
kandang penampungan dimana ruang yang cukup ketika ternak berdiri, dapat mengambil posisi berbaring yang normal, serta dilihat dari kebersihan lantai dari kotoran ternak, bentu atap kandang serta ketersedian tempat air minum dan pakan.

Pemeriksaan antemortem yang dilakukan oleh petugas UPT RPH Battembat (DISTANBUNNAKHUT) Kabupaten Cirebon atau jagal dan dikeluarkan surat keterangan sehat. Menurut hasil penelitian (Bhaskara et al., 2015) mengatakan bahwa pemeriksaan antemortem yang dilakukan oleh RPH Kotamadya Banda Aceh melihat tingkah laku ternak selama di kandang penampungan. Menurut (MLA, 2012) mengatakan bahwa pemeriksaan antemortem di RPH/TPH sesuai SOP Kesehatan Ternak tidak hanya pengamatan tingkah laku pada ternak saja tetapi juga dilihat dari kotoran segar dan asupan pakan atau air selama di kandang penampungan.

\section{Proses Pemotongan Ternak}

Proses pemotongan ternak dilakukan pada malam hari pukul 00.00 WIB sampai selesai. Pemotongan di TPH Sumber Rejeki ini sesuai dengan pesanan dari pelanggan tetap atau tidak, hal ini dilakukan untuk dapat memprediksi jumlah ekor yang harus dipotong dan mendistribusikan daging dengan cepat. Proses pemotongan sapi sesuai dengan proses syariat islam dimana ternak diikat kemudian direbahkan dan dipotong ketiga saluran yaitu saluran nafas, saluran pencernaan dan saluran darah tak lupa membaca lafadz basmallah atau bismillahi allahu akbar sebelum pisau memotong tiga saluran di leher serta membuat irisan dari arah leher ke jantung. Penusukan ke jantung ini bertujuan untuk mempercepat dan menyempurnakan pengeluaran darah. Sapi dan kerbau tidak memberikan rangsangan gerak dan lamanya sekitar 3 menit, setelah itu ternak sapi dinyatakan mati. Hal ini sesuai dengan hasil penelitian (Rosyidi, 2017) mengatakan bahawa penyembelihan secara islami yaitu terdiri dari Ternak disembelih menghadap kiblat mengucapkan bacaan basmallah atau tahmid, dipotongnya ketiga saluran di leher dan jantung ditusuk (bleeding), kemudian ditunggu sampai benar mati dan darah keluar secara tuntas, setelah itu dipisahkan kepala dari tubuh. Hal ini sesuai juga dengan Menurut (MLA, 2012) yang mengatakan bahwa sesuai dengan SOP kesejahteraan ternak, maka penyembelihan harus dilakukan dengan sekali tebas menggunakan pisau yang tajam. Pendarahan yang kurang maksimal dapat diambil dengan melakukan penusukan kedua menggunakan pisau yang berbeda.

\section{Penanganan Daging Pasca Pemotongan}

Penangan daging pasca pemotongan ini ada beberapa tahap yaitu : 1 . Pemotongan kepala dan kaki. 2. pengulitan, 3. pengeluaran organ dalam, 4. Pemotongan karkas, 5. Pemeriksaan setelah pemotongan, 6 . Penimbangan karkas. Tahap-tahapan di atas dilakukan oleh pihak TPH Sumber Rejeki tidak hanya menyembelih ternak saja tetapi juga sebagai bentuk layanan yang diberikan kepada pihak konsumen sehingga pelanggan menerima dalam bentuk bersih karkas yang sudah dipisah daging dan tulang, sedangkan untuk kepala, kulit dan kaki diberikan kepada pihak TPH Sumber Rejeki. Hasil penelitian (Rosyidi, 2017) mengatakan bahwa proses penyiapan daging yaitu terdiri dari 1) pemisahan kepala dari tubuh ternak dan keempat kakinya, 2) pengulitan tubuh, 3) pengeluaran organ dalam (rumen, lambung, hati, jantung, paru-paru dan trakhea. 4) Pisahkan karkas bagian kiri dan kanan dengan gergaji tepat. 5) memotong bagian-bagian karkas yang dianggap kurang bermanfaat, kemudian dibungkus dan ditimbang karkas. 6) Pemeriksaan postmortem (pemeriksaan kelenjar limfe, kepala bagian mulut, lidah, bibir, otot maseter (pipi), paru-paru, jantung, ginjal, hati, serta limpa).

\section{Physical Evidence (Bukti Fisik)}

Bukti fisik yang diberikan oleh TPH Sumber Rejeki adalah Nota pembayaran, Nota Jumlah Penimbangan karkas, label sertifikat Halal dari MUI ke produk daging. Konsumen yang membutuhkan jasa pemotongan ternak pasti diberikan oleh pihak TPH berupa Nota 
pembayaran jasa sebesar Rp 1.000.000/ekor, Nota jumlah penimbangan karkas dan label sertifikat halal.

\section{Customer Service (layanan pelanggan)}

Layanan pelangan yang diberikan oleh TPH sumber Rejeki yaitu 1. Label sertifikat halal dimana proses pemotongan ternak sesuai syariat islam yang Halal Thoyiban, 2. Daging sesuai permintaan konsumen dikemas dalam ukuran $0,5 \mathrm{~kg}$ atau $1 \mathrm{~kg}, 3$. TPH sumber rejeki diantar sampai ke konsumen atau delivery order dan tidak ditanggung biaya transportasi serta siap diantar 24 jam. 4. Daging bisa di retur apabila tidak sesuai dengan permintaan konsumen.

\section{KESIMPULAN}

Berdasarkan hasil penelitian ini dapat disimpulkan bahwa, kegiatan bauran pemasaran yang ada di TPH Sumber Rejeki masih semi tradisional dimana sistemnya sudah menggunakan teknologi tetapi belum semuanya misal: 1) bantuan teknologi dalam pemasaran dan ruang penyimpanan produk daging (Ruang Cooling). 2) penyembelihan hewan ternak masih menggunakan tradisional, 3) diversifikasi produk sehingga produk utama sampai yang hasil ikutan (kulit) diolah dan mempunyai value added. 3) Tempat usaha yang strategis dengan pasar Plered, Kanoman dan Indramayu. 4) Harga daging setiap pedagang punya selisih Rp $5.000-\mathrm{Rp}$ 10.000 jadi tidak ada yang dirugikan.

\section{DAFTAR PUSTAKA}

Astuti, F. K., Suroto, K., dan Santoso, E. 2019. Analisis Bauran Pemasaran Terhadap Perilaku Konsumen Daging Sapi Dan Implikasi Strategi Pemasaran Di Hypermart Kota Malang. Buana Sains, 19(1): 25-36.

Azwanda, Sani, L. A., dan Aka, R. 2017. Analisis Profitabilitas Usaha Jagal Sapi Di Rumah Potong Hewan Kota
Kendari. JITRO, 4(2): 10-18.

Budi Rahayu Tanama Putri, I Wayan Budiartha, Suciani, Ketut Warsa Parimartha, I Wayan Sukanata. I Gst Ngurah Kayana. 2016. Diktat Marketing Produk Peternakan. Fakultas Peternakan Universitas Udayana. Bali.

Bhaskara, Y., Adam, M., Nasution, I., Lubis, T. M., Armansyah, T., dan Hasan, M. 2015. Tinjauan aspek kesejahteraan hewan pada sapi yang dipotong di rumah pemotongan hewan Kotamadya Banda Aceh. Jurnal Medika Veterinaria, 9(2): 149-153.

Dhiba, I. D. S., \& Maduwinarti, A. 2014. Analisis Pengaruh Bauran Pemasaran Jasa Terhadap Minat Pengunjung Pada Obyek Wisata Museum Kesehatan Dr. Adhyatma, MPH Surabaya Ich. Jurnal Ilmu Ekonomi \& Manajemen, 1(1): 94-109.

Emawati, F., Imanningsih, N., Nunung, N., Sahara, E., Sundari, D., Arifin, A. Y. dan, \& Mutiara, P. 2018. Nilai Ph Dan Kualitas Zat Gizi Makro Daging Beku, Dingin Dan Segar Pada Pasar Tradisional Dan Pasar Swalayan $(\mathrm{Ph}$ And Macronutrition Of Frozen, Cold And Fresh Beef In Traditional Markets And Supermarkets) Fitrah. Penelitian Gizi Dan Makanan, 14(3): 37-45.

Firman, A., Sulaeman, M. ., Herlina, L. dan, dan Sulistyati, M. 2018. Analisis Neraca Pasokan Dan Kebutuhan Sapi Dan Daging Sapi Di Jawa Barat. Jurnal Pemikiran Masyarakat Ilmiah Berwawasan Agribisnis, 04(02): 98108.

Firmansyah, M. A. (2019). Buku Pemasaran Produk Dan Merek. Penerbit CV Qiara Media. Surabaya.

Gunawan, L. (2013). Analisa Perbandingan Kualitas Fisik Daging Sapi Impor Dan Daging Sapi Lokal. Jurnal Hospitality dan Manajemen Jasa, 53(9): 16891699. 
Handayani, S., Fariyanti, A., dan Nurmalina, R. 2016. Swasembada Daging Sapi Analisis Simulasi Ramalan Swasembada Daging Sapi di Indonesia. Sosiohumaniora, 18(1): 61-70.

Kotler, P. dan G. Armstrong. 2008. Prinsipprinsip Pemasaran (Terjemahan). Penerbit Erlangga. Jakarta.

Kotler, P. 2005. Manajemen Pemasaran. Penerbit Indeks Media Group. Jakarta.

Kotler, P. 2014. Manajemen Pemasaran Analisis, Perencanaan, Implementasi dan Kontrol. Edisi Keempat belas. Edisi Bahasa Indonesia. PT. Prenhallindo. Jakarta.

Narundhana, D., Tawaf, R. dan Arief, H. 2015. Faktor-Faktor Yang Mempengaruhi Pemotongan Sapi Bandung. Student E-Journal.

Panjaitan, H. dan Cahyanto, H. 2017. Analisis Pengaruh Bauran Pemasaran Terhadap Keputusan Pembelian Pakan Ternak
Ayam Pedaging di Kabupaten Jombang Jawa Timur. Jurnal Ilmu Ekonomi Dan Manajemen, 4(1): 14-23.

Priyanti, A. dan Inounu, I. 2016. Perilaku Harga Produk Peternakan Pada Hari Besar Keagamaan Nasional. Analisis Kebijakan Pertanian, 14(2): 149-162.

Rosyidi, L. H. 2017. Strategi Bersaing Usaha Potong Ternak (Study Kasus Rph Jagal Syari'ah Kecamatan Pesanggaran Kabupaten Banyuwangi). Jurnal Ekonomi Dan Hukum Islam, 8(2): 154-173.

Selang, C. A. D. 2013. Bauran Pemasaran (Marketing Mix) Pengaruhnya Terhadap Loyalitas Konsumen pada Fresh Mart Bahu Mall Manado. Jurnal EMBA. 1(3): 71-80

Sumarni, Murti dan Soeprihanto, J. 2010. Pengantar Bisnis (Dasar-dasar Ekonomi Perusahaan). Edisi ke 5. Penerbit Liberty. Yogyakarta. 